\title{
Recenzja
}

\section{Tryb zmiany konstytucji w wybranych państwach członkowskich Unii Europejskiej, pod red. Katarzyny Kubuj, Jana Wawrzyniaka, Biuro Trybunału Konstytucyjnego, Warszawa 2010, ss. 230}

Konstytucja stanowi fundament funkcjonowania państwa i słusznie oczekuje się, że będzie bardziej niezmienna od aktów prawnych stojących niżej w hierarchii źródeł prawa. Z drugiej zaś strony, ustawa zasadnicza powinna odpowiadać rzeczywistości społecznej, w której funkcjonuje. Ta zmienna rzeczywistość - jak podkreślają redaktorzy naukowi recenzowanej pracy (s. 7) - znajduje odbicie w treści konstytucji państw członkowskich UE, w których szereg zmian miał związek m.in. z przynależnością do UE. Udział państw w UE wymaga bowiem podjęcia szeregu decyzji o charakterze konstytucyjnym, niezbędnych dla przystosowania prawa krajowego do członkostwa $\mathrm{w}$ organizacjach międzynarodowych szczególnego rodzaju. Z zasadą kształtującą relacje pomiędzy prawem krajowym a prawem unijnym nieustannie muszą się mierzyć ustawodawca krajowy oraz organy stosujące prawo. Próba ustalenia podstawowych prawidłowości i uwarunkowań dotyczących zmian w konstytucjach państw członkowskich UE stał się głównym motywem, który skłonił Zakład Prawa Konstytucyjnego i Badań Europejskich Instytutu Nauk Prawnych Polskiej Akademii Nauk do podjęcia badań w ramach projektu zatytułowanego „Motywacja i charakter zmian w konstytucjach państw członkowskich Unii Europejskiej, jako wyraz europeizacji prawa konstytucyjnego", finansowanego przez Ministerstwo Nauki i Szkolnictwa Wyższego.

Zespół badawczy, złożony z doświadczonych znawców prawa konstytucyjnego, poszukiwał w szczególności odpowiedzi na pytania: 1) czy zakres i tempo zmian konstytucyjnych są adekwatne do dynamicznie rozwijającego się otoczenia społecznego, politycznego, międzynarodowego; 2) czy uprawnione jest formułowanie tezy o tendencjach zmian w konstytucjach, które dotyczyłyby większej liczby państw; 3) czy w warunkach państw członkowskich UE występują prawidłowości o specyficznym dla nich charakterze; 
4) czy relacje między prawem unijnym i krajowym prowadzą do nowego statusu konstytucji w wewnętrznym systemie źródeł prawa; 5) czy między rozmaitymi grupami państw - członków UE występują znaczące różnice w rozwiązaniach konstytucyjnych; 6) czy różnice te pogłębiają się, czy raczej następuje ich niwelacja; 7) czy można wskazać główne kierunki zmian w konstytucjach państw członkowskich UE (s. 7).

Ten bogaty katalog szczegółowych zagadnień badawczych spowodował konieczność realistycznego rozłożenia badań z punktu widzenia liczby państw, które miały podlegać badaniu, a także dokonania ogólnej kategoryzacji wymienionych zagadnień. Zespół badawczy dokonał wyboru państw. Aby zminimalizować arbitralność tego wyboru, postanowiono przyjąć kryteria o możliwie obiektywnym charakterze. Uznano, że wśród wybranych państw powinny być reprezentowane wszystkie grupy przyjmowane w rożnym czasie, w toku istnienia najpierw EWG, później UE. Starano się także uwzględnić zarówno państwa mające ugruntowaną pozycję w UE, jak i te, które o taką pozycję dopiero zabiegają. Wreszcie starano się nie pominąć państw, o których wiadomo, że wyróżniają się oryginalnością. Ostatecznie lista badanych państw przedstawia się następująco: Austria, Czechy, Finlandia, Francja, Irlandia, Litwa, Niemcy, Polska, Portugalia, Rumunia, Słowacja, Słowenia, Wielka Brytania i Włochy (s. 8).

Dokonany wybór wydaje się prawidłowy, choć zawsze można by przytoczyć argumenty także za innymi państwami członkowskimi UE. Ustrój Danii wart był dostrzeżenia ze względu na szczególnie silną pozycję parlamentu w oddziaływaniu na mandat tego państwa prezentowany na forum Rady UE, co wiąże się też z wpływami komisji parlamentarnej podejmującej sprawy europejskie, zaliczanej do kategorii wielkich komisji europejskich. Hiszpania byłaby interesująca ze względu na specyfikę oddziaływania regionów na sprawy europejskie. Można było też dostrzec któreś z państw z południowej flanki UE (Cypr, Malta).

Wielość opracowań pozwala na jedynie ich krotką prezentację, wydobywającą najistotniejsze obszary badawcze.

Maria Kruk przedstawiła zmiany konstytucji na tle zasad trybu ustawodawczego Republiki Czeskiej, prezentując zarówno ogólną charakterystykę zmian konstytucji (s. 18), jak i kolejne fazy proceduralne (s. 22). Osobny punkt Autorka poświęciła zmianom konstytucji związanym z członkostwem Republiki Czeskiej w Unii Europejskiej (s. 36). 
Nieco inną metodologię zastosował Marian Grzybowski w opracowaniu dotyczącym zmian konstytucji Finlandii w kontekście członkostwa w Unii Europejskiej. W pierwszej części opracowania skoncentrował się na tych elementach, które są bezpośrednio powiązane z procesem integracji europejskiej: przystąpienie do UE a zmiana regulacji konstytucyjnych w Finlandii (s. 44) oraz rola Eduskundy w opiniowaniu projektów aktów prawa wspólnotowego i decyzji (aktów) Unii Europejskiej jako przejaw „przenikania się” prawodawstwa europejskiego i krajowego (s. 45). Dopiero w drugiej części poddał analizie przygotowanie i opracowanie jednolitej regulacji konstytucyjnej - Konstytucja z 11 czerwca 1999 r. (s. 46) oraz tryb zmiany konstytucji w ujęciu Konstytucji Finlandii z 11 czerwca 1999 r. (s. 47).

Opracowanie Katarzyny Kubuj dotyczy trybu zmiany Konstytucji V Republiki Francuskiej. Autorka przedstawiła strukturę konstytucji (s. 55) i warunki przeprowadzenia zmiany konstytucji (s. 57). Zwróciła uwagę na kontrowersyjną praktykę związaną z trybem zmiany określonym $\mathrm{w}$ art. 11 Konstytucji (s. 65). Z pola widzenia Autorki zniknęły natomiast kwestie związane z członkostwem Francji w UE.

Analiza Piotra Radziewicza dotyczy procedury zmian Konstytucji Irlandii. W opracowaniu tym dominują generalne rozważania konstytucyjne dotyczące relacji ustrojowych między konstytucyjnymi organami państwa (s. 77) i systemu organizacyjnego sądownictwa konstytucyjnego (s. 81). Autor wyeksponował też promulgację i kontrolę konstytucyjności (s. 83). W tej sytuacji procedura zmiany konstytucji potraktowana została dość zdawkowo, na trzech stronach tekstu. Nie wskazano też na kwestie związane z członkostwem Irlandii w Unii Europejskiej.

Krzysztof Budziło przedstawił procedurę zmiany konstytucji w Republice Litewskiej. Szczegółowo przedstawione zostały rozwiązania, które niesie Konstytucja z 1992 r. (s. 91). Autor przedstawił też zmiany dokonane w obowiązującej konstytucji (s. 103). Nie odniósł się natomiast szczegółowo do konsekwencji członkostwa Litwy w UE.

Analiza Stanisława Witkowskiego dotyczy procedury zmiany konstytucji w Republice Federalnej Niemiec. Szczególny nacisk położył Autor na tryb zmiany ustawy zasadniczej (s. 108), eksponując konstytucyjnie zastrzeżone materie (s. 110) oraz rolę Federalnego Trybunału Konstytucyjnego (s. 118). Podjął też zagadnienia związane z referendum (s. 120). Nie odniósł się natomiast do kwestii członkostwa RFN w UE. 
Marzena Laskowska zaprezentowała tryb zmiany konstytucji w Polsce ze szczególnym uwzględnieniem nowych elementów proceduralnych i praktyki. Odniosła się do dylematu: ustawa o zmianie konstytucji czy ustawa konstytucyjna? (s. 131). Wyeksponowała też kwestię przepisów zmienianych w procedurze kwalifikowanej oraz tzw. przepisów niezmienianych (s. 133). Podkreśliła też znaczenie referendum zatwierdzającego ustawę o zmianie konstytucji (s. 155). Autorka nie odniosła się natomiast bezpośrednio do kwestii konsekwencji konstytucyjnych akcesji Polski do UE.

Anna Łabno, prezentując zasady zmiany Konstytucji Portugalii, skoncentrowała się na typologiach zmian konstytucji z 1976 r.: zmianie zwykłej i zmianie nadzwyczajnej (s. 170). Poddała też analizie materialne granice dopuszczalności nowelizacji konstytucji (s. 172) oraz procedurę uchwalania nowelizacji konstytucji (s. 176). Autorka nie nawiązała natomiast bezpośrednio do kwestii związanych z członkostwem Portugalii w UE.

Opracowanie Jacka Falskiego dotyczy trybu zmiany Konstytucji Rumunii. Autor wyeksponował kwestie związane z integracją Rumunii z Unią Europejską i NATO (s. 184). Zaprezentował też - choć w sposób bardzo syntetyczny - tryb zmiany konstytucji (s. 185).

Artykuł Jerzego Ciemniewskiego dotyczy procedury zmiany konstytucji w Republice Słowenii. Zaprezentowane zostały źródła prawa konstytucyjnego (s. 196) oraz sama procedura zmian (s. 199). Nie ma natomiast odniesień do członkostwa Słowenii w UE.

Ewa Popławska przedstawiła zmiany ustrojowe w Zjednoczonym Królestwie. Choć w państwie tym nie ma konstytucji w sensie formalnym, to jednak uwzględnienie go uznać można za uzasadnione, choćby ze względu na wagę jego doświadczeń ustrojowych. Autorka szczególnie wyeksponowała kwestię ustawy i zobowiązań międzynarodowych w świetle zasady suwerenności Parlamentu (s. 208). Specjalny punkt został poświecony przystąpieniu Zjednoczonego Królestwa do Wspólnot Europejskich (s. 215).

Wreszcie Jan Wawrzyniak ukazał podstawowe procedury dotyczące zmian konstytucji w Republice Włoskiej. Przedstawił procedurę uchwalania ustaw rewidujących konstytucję i innych ustaw konstytucyjnych (s. 222), a także relacje między izbami parlamentu w procedurze zmian konstytucyjnych (s. 224). Wskazał też na materię konstytucyjną niezmienialną (s. 227). Nie odniósł się natomiast szczegółowo do kwestii konstytucyjnych konsekwencji członkostwa Włoch w UE. 
Przedstawiona sygnalizacja wskazuje, że mamy tu do czynienia z rożnym podejściem metodologicznym. Dają tu o sobie znać zarówno temperamenty autorskie, jak i prezentowane przez nich specjalizacje. Może być jednak postawione pytanie, czy nie byłby tu przydatny pewien wysiłek w kierunku ujednolicenia opracowań, poprzez uzgodnienie pewnego schematu. Okazuje się bowiem, że część autorów (M. Kruk, M. Grzybowski, F. Falski, E. Popławska) odczytała sygnał płynący z tytułu („w wybranych państwach członkowskich UE") jako zachętę do podjęcia konstytucyjnej problematyki członkostwa tych państw w UE. Inni autorzy najwidoczniej uznali jednak, że z tytułu nie wynika taka intencja. Tak czy inaczej, warto było określić w jakim kontekście występuje tu sygnalizacja UE i z jakiej motywacji odniesiono się tylko do wybranych państw z grona członkowskiego tej organizacji międzynarodowej. Ukazałoby by to być może związek przyczynowy pomiędzy problematyką zmiany konstytucji a zagadnieniami integracji europejskiej. Jest bowiem rzeczą oczywistą, że znaczna część dokonywanych zmian ustawy zasadniczej dotyczyła właśnie konsekwencji członkostwa tych państw w UE.

Nie wiadomo też, jakie kryterium decydowało o objętości poszczególnych opracowań. Wystąpiły tu znaczące dysproporcje: $\mathrm{z}$ jednej strony Polska (42 strony) i Czechy (28 stron), z drugiej strony Rumunia (10 stron) i Słowenia (12 stron). Musiało to rzutować na szczegółowość przygotowanych opracowań.

Być może przydałby się dodatkowy rozdział syntetyzujący rozważania, choćby podług kryteriów, jakie przyświecały autorom w podjęciu tych badań. Ułatwiłoby to pełniejszą orientację w kwestii zastosowanych modeli rozwiązań konstytucyjnych oraz wydobyło prawidłowości, jakie członkostwo w UE niesie dla treści ustaw zasadniczych państw członkowskich.

Można też odnotować pewną kwestię techniczną. Wydawca książki inaczej jest określony na stronie tytułowej (Trybunał Konstytucyjny Wydawnictwa), inaczej na stronie 2, gdzie zawarte są informacje o książce (Biuro Trybunału Konstytucyjnego). Powinno tu być jednolite ujęcie, ułatwiające cytowanie tej pracy.

Recenzowane opracowanie niesie niewątpliwie wartościowe informacje. Należy zwłaszcza zwrócić uwage na jego walor dydaktyczny, w procesie nauczania prawa konstytucyjnego porównawczego. Będzie też zapewne służyć jako inspiracja do dalszych analiz szczegółowych tego zagadnienia. 
Nie można też wykluczyć, że będzie ponadto punktem odniesienia dla wniosków de lege fundamentali ferenda, gdyby doszło do nowelizacji czy zmiany Konstytucji RP.

Jerzy Jaskiernia

(Uniwersytet Humanistyczno-Przyrodniczy Jana Kochanowskiego w Kielcach) 